DOI: $10.20472 /$ IAC.2018.037.015

\author{
ANITA SCHILLER \\ University Of Dundee, United Kingdom \\ DAKSHINA DE SILVA \\ Lancaster University, United Kingdom \\ ROBERT MCCOMB \\ Texas Tech University, United States \\ AURELIE SLECHTEN \\ Lancaster University, United Kingdom
}

\title{
THE ENVIRONMENTAL KUZNETS CURVE IN SMALL GEOGRAPHIES
}

\begin{abstract}
:
Finding a theoretical explanation of the Environmental Kuznets Curve (EKC) has been difficult. Given that environmental quality improves as income and consumption increase, ceteris paribus, there must be an increase in remediation/abatement activity. In this paper, we provide theoretical conditions for an existence of a locality-based EKC when both output and abatement expenditures are increasing in income. We validate these predictions empirically using a detailed firm-level dataset in which environmental policies are uniform across locations. We also show that firms engaging in abatement activity tend to locate near polluting firms while income also plays a significant role in location choice.
\end{abstract}

\section{Keywords:}

EKC, Environmental Economics, Agglomeration, Entry and Exit.

JEL Classification: Q50, R00, L00 